\title{
Effect of double-muscling and of removing straw, fed besides concentrates, on the chewing behaviour of bulls*
}

\author{
S. De Campeneere ${ }^{1}$, A. Van Herck, L.O. Fiems \\ and D.L. De Brabander \\ Department Animal Nutrition and Husbandry, Agricultural Research Centre \\ Scheldeweg 68, B-9090 Melle, Belgium
}

\begin{abstract}
To determine if beef bulls adjust their chewing pattern to avoid ruminal acidosis, the chewing behaviour of double-muscled $(\mathrm{dm})$ and non-dm bulls was studied with a concentrate based diet, with and without straw. The conformation (dm or not) had no influence on chewing behaviour. The removal of the straw resulted in an importantly increased DM-intake. When fed $100 \%$ concentrates, significant rumination activity was recorded. Removing the roughage from the diet had no influence on time of eating, but induced a slight shift towards relatively more rumination during the second half of the day.
\end{abstract}

KEY WORDS: chewing behaviour, concentrates, double-muscling, bulls, ruminal acidosis, straw

\section{INTRODUCTION}

The ability of ruminants to control feed intake is long known. Chase et al. (1976) stated that steers can vary the size or the number of meals to control feed intake. If bulls adjust their eating and ruminating pattern to avoid ruminal acidosis when physical structure supply is marginal, is unkown. E.g., bulls could reduce the acid load for the rumen by shifting rumination more towards the time that the acid load is highest. The extra amount of saliva produced during rumination would then give additional buffer capacity to the rumen (Okamoto, 1976). By spreading the meals over the total day period, rumen acid load could also be reduced.

Chewing behaviour was studied with a concentrate based diet, with and without straw. By using double-muscled (dm) and non-dm bulls the influence of

\footnotetext{
* Supported by the Ministry of the Flemish Community, IWT

${ }^{1}$ Corresponding author: e-mail: s.decampeneere@clo.fgov.be
} 
the conformation on chewing behaviour was investigated. The bulls dm have a different intake capacity (Fiems et al., 1997). However, if they also have a different eating pattern was never investigated.

\section{MATERIAL AND METHODS}

During the first week 12 Belgian Blue bulls ( $6 \mathrm{dm}$ and 6 non-dm; \pm 18 months) were fed $12 \%$ straw (NDF content: $71 \%$ of DM) and $88 \%$ concentrate (C; NDF content: $38 \%$ of DM) (DM-basis). After that week, the dietary roughage part decreased slowly each week until 100\% C was fed, 4 weeks later. The structural value of the straw and the C, calculated according to De Brabander et al. (1999), amounted to 4.30 and 0.27 per $\mathrm{kg}$ DM. The mixed rations were fed individually to appetite in one meal at $9.00 \mathrm{a} . \mathrm{m}$. The grains in the $\mathrm{C}$ were rolled, other ingredients remained unground. The animals were tied, had individual mangers and free access to water. Wood shavings were used as bedding. During the 5th, 6th and 7 th day of the first (12\% straw) and last week $(100 \%$ C) chewing behaviour was recorded using a head-halter recording chewing movements digitally. For each day the number of periods and the time spent eating, ruminating and idling was calculated. Data were divided into $24 \mathrm{~h}$ periods and for each hour, the time spent eating, ruminating and idling was expressed in min and as \% of the total daily eating, rumination and idling time.

\section{RESULTS AND DISCUSSION}

The 12 bulls weighed $609 \pm 50 \mathrm{~kg}$ during the $12 \%$ straw week and $632 \pm 47 \mathrm{~kg}$ during the $100 \% \mathrm{C}$ week. Intake and chewing parameters are listed in Table 1.

Table 1 Intake and chewing parameters for diets based on $\mathrm{C}$ with $12 \%$ or $0 \%$ straw

\begin{tabular}{|c|c|c|c|c|c|c|c|c|}
\hline \multirow{2}{*}{\multicolumn{2}{|c|}{$\begin{array}{l}\text { Conformation } \\
\text { Portion of straw, } \%\end{array}$}} & \multicolumn{2}{|c|}{ Non-dm } & \multicolumn{2}{|c|}{$\mathrm{dm}$} & \multirow{3}{*}{ SEM } & \multicolumn{2}{|c|}{ P-value } \\
\hline & & 12 & 0 & 12 & 0 & & $\mathrm{Dm} /$ & $\%$ \\
\hline \multicolumn{2}{|c|}{ Number of animals } & 6 & 6 & 6 & 5* & & non-dm & straw \\
\hline \multirow[t]{4}{*}{ Intake } & $\mathrm{kg} \mathrm{DM} /$ day & 8.4 & 10.2 & 7.1 & 9.8 & 0.3 & 0.06 & $<0.001$ \\
\hline & MJ NE/day & 58.8 & 78.4 & 49.9 & 70.7 & 1.9 & 0.07 & $<0.001$ \\
\hline & g DM/kg LW 0.75 & 67.4 & 79.6 & 58.6 & 79.7 & 2.2 & 0.13 & $<0.001$ \\
\hline & g NDF/ $/ \mathrm{kg} \mathrm{LW} \mathrm{LW}^{0.75}$ & 28.5 & 30.4 & 24.8 & 30.5 & 0.7 & 0.10 & $<0.01$ \\
\hline \multirow[t]{3}{*}{ Eating } & periods/day & 19.4 & 20.5 & 17.7 & 17.3 & 0.9 & 0.18 & 0.86 \\
\hline & $\mathrm{min} /$ day & 179 & 151 & 166 & 141 & 7 & 0.35 & 0.044 \\
\hline & $\min / \mathrm{kg} \mathrm{DM}$ & 21.5 & 15.4 & 24.4 & 14.4 & 1.2 & 0.59 & $<0.001$ \\
\hline \multirow[t]{3}{*}{ Rumination } & periods/day & 15.9 & 8.8 & 16.1 & 10.4 & 0.9 & 0.51 & $<0.001$ \\
\hline & $\min /$ day & 506 & 209 & 463 & 167 & 40 & 0.39 & $<0.001$ \\
\hline & $\mathrm{min} / \mathrm{kg} \mathrm{DM}$ & 60.6 & 19.3 & 67.7 & 16.9 & 5.5 & 0.65 & $<0.001$ \\
\hline
\end{tabular}

* during the trial $1 \mathrm{dm}$ bull showed signs of acute acidosis and was removed from the trial 


\section{Effect of conformation}

There was no effect of conformation on any of the parameters measured. There was a tendency for the intake to be lower in $\mathrm{dm}$ compared to non-dm bulls. This tendency was most pronounced $(\mathrm{P}=0.06)$ when the intake was expressed in DM. Thus, no indications were found of an influence of the conformation on the chewing behaviour.

\section{Effect of removing straw}

Daily DM and energy intake of the $100 \% \mathrm{C}$ was, respectively, 23 and $27 \%$ higher than for the diet with straw. This indicates that $12 \%$ straw strongly reduced ad libitum intake. This was most pronounced for the dm bulls ( 28 vs $18 \%$ for the DM-intake). Due to this increased DM-intake, NDF intake was higher for the $100 \% \mathrm{C}$ diet. Despite the higher intake for the $100 \% \mathrm{C}$, the number of meals was not influenced. The time spent eating, however, decreased on average by $15 \%$. There was a much greater decrease in the number and the duration of rumination periods. However, it is quite surprising that even at $100 \% \mathrm{C}$, bulls spent $188 \mathrm{~min}$ ruminating daily or about 18 min per $\mathrm{kg} \mathrm{DM}$ of $\mathrm{C}$.

In contrast to earlier studies with cows fed $100 \% \mathrm{C}$ (grain-based) diets where regular mastications were seldom seen (Freer and Campling, 1965), in this experiment several periods of rumination were recorded at $100 \% \mathrm{C}$. Probably, the high amount of pressed sugar beet and citrus pulp in the $\mathrm{C}$ (total 44\%) caused the extra rumination time. De Brabander et al. (1999) found that Holstein cows eat and ruminate on average 7.7 and 14.0 min per $\mathrm{kg}$ DM of dried sugar beet pulp, whereas the rumination time for cereals is mostly considered negligible.

\section{Hourly chewing pattern}

Only small differences existed between the diets in eating and rumination activity over a 24-h interval (Figure 1). Eating took place in the first $12 \mathrm{~h}$ postprandial. The most important meal was recorded during the first $\mathrm{h}$ after feeding, since between 17 and $23 \%$ of total eating time occurred in that period.

The presence of $12 \%$ straw in the ration increased the eating time by about 14 $\mathrm{min}$ in the first $\mathrm{h}$ after feeding. Removing the straw, reduced the rumination time in the first half of the day from 40 to $30 \%$. At the same time, no important shift in relative eating time was found. The moderate shift towards more nocturnal rumination implies that total chewing time during the first half of the day (when by far the largest part of the feed is eaten and the acid load for the rumen is highest) is relatively lower for the $100 \% \mathrm{C}$ diet. These results indicate that the bulls did not adapt their chewing pattern to improve the buffering capacity of the rumen at the time the ruminal acid load was highest. 


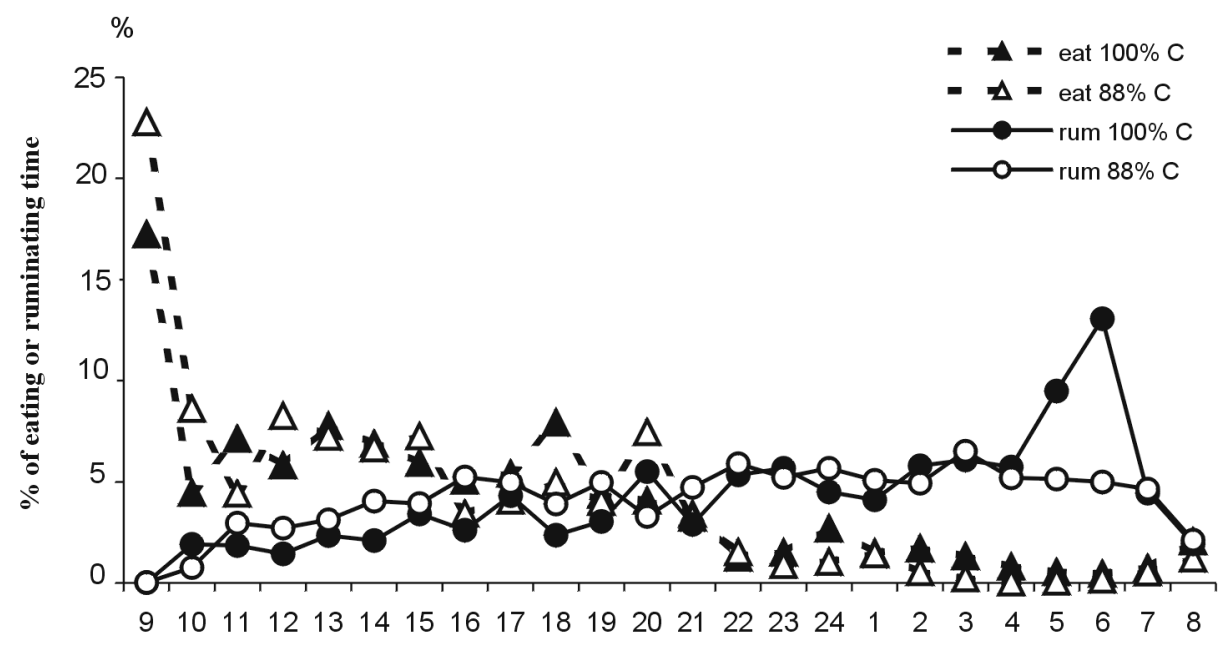

Time of day, feeding at 9.00 a.m.

Figure 1. Percent of the daily eating (eat) or ruminating (rum.) time spent during each hour of the day (h postprandial) for diets with 100 or $88 \% \mathrm{C}$

\section{CONCLUSIONS}

The conformation of the animal had only limited influence on chewing behaviour. The removal of the straw resulted in an importantly increased DMintake. Even when the concentrate was fed at $100 \%$, significant rumination activity was recorded. Removing the roughage had no influence on eating pattern, but induced a shift towards relatively more rumination during the night period. This indicates that bulls did not adapt their chewing pattern to improve the buffering capacity of the rumen at the time of the highest ruminal acid load.

\section{REFERENCES}

Chase L.E., Wangsness P.J., Baumgardt B.R., 1976. Feeding behaviour of steers fed a complete mixed ration. J. Dairy Sci. 59, 1923-1928

De Brabander D.L., De Boever J.L., Vanacker J.M., Boucqué Ch.V., Botterman S.M., 1999. Evaluation of physical structure in dairy cattle nutrition. In: P.C. Garnsworthy, J. Wiseman (Editors). Recent Advances in Animal Nutrition. University Press, Nottingham, pp. 111-145

Fiems L.O., Cottyn B.G., Boucqué Ch.V., Bogaerts D.F., Van Eenaeme C., Vanacker J., 1997. Effect of beef type, body weight, and dietary protein content on voluntary feed intake, digestibility, blood and urine metabolites and nitrogen retention. J. Anim. Physiol. Anim. Nutr. 77, 1-9

Freer M., Campling R.C., 1965. Factors affecting the voluntary intake of food by cows. Brit. J. Nutr. $19,195-207$

Okamoto M., 1976. Diurnal variation in rumen $\mathrm{pH}$ and diurnal distribution of rumination and the relationship between them. Jpn. J. Zootech. Sci. 47, 672-678 